\title{
INDIAN PERSPECTIVE OF SMART CITIES AND THEIR SUSTAINABLE GROWTH
}

\author{
JADI BALA KOMARAIAH \& ISHA DUBE \\ Banaras Hindu University, India
}

\begin{abstract}
Ambiguity for the term smart city has led to intensive research in this area for providing a justifiable definition which includes all its aspects. One finds that the acceptance of Internet of Things (IOT) and Information and Communication Technologies (ICT) playing a major role in facilitating the cities for better utilisation of their available resources, is a universal truth. Cities extensively use the technology in almost any activity which can make them smart. According to the World Bank, India continues to be one of the fastest growing economies in the world and predicts it to be a global economic power in the coming years. Further, India's increasing focus on research and development has stirred the investors across the globe to invest in this country. Despite of the political, social, environmental factors hindering its growth, India continues to progress towards urbanisation with almost 39 cities inhabiting more than a million people. The flagship programmes like Atal Mission for Rejuvenation and Urban Transformation (AMRUT), Mission for development of 100 smart cities, Swachh Bharat Abhiyan are continually working on making the Indian cities grow sustainably. In the European Union, smart city initiatives are focusing majorly on smart environment which attracts us to study such programmes in which one can learn from both European Union and India perspectives. As a result, dynamic policy making initiatives would be incorporated in their respective policies. This paper will apprise what other countries can learn from Indians particularly the best techniques for growing to develop the smart and sustainable green cities. It will aid the policy makers to frame the suitable policies on the basis of experience.

Keywords: smart city, sustainable green cities, energy management, policy making.
\end{abstract}

\section{INTRODUCTION}

According to UN report of 2016 [1], around 54.5 percent of the world's population resides in urban settlements in 2016 and predicts this myriad to increase even further with the rural- urban migration. While driving towards economic growth, urban population have led to anthropogenic environmental degradation resulting into resource depletion and climate change. Undoubtedly, human capital can play a major role in assuaging this impact contributing towards the sustainability drive of a country. Hence, discerning this fact, many countries across the world have formulated their objectives of promoting inclusive development through their smart city programmes by channelizing human skills to conserve the non-renewable natural resources.

"Europe 2020" [2] is one such strategy adopted by European Union to obtain a smart, sustainable and inclusive growth by the year 2020 with innovations as one of its primary focus. Since the establishment of this strategic plan, there have been number of measures and techniques deployed in cities which had positive impact on environment.

According to the World Bank, India continues to be one of the fastest growing economies [3] in the world. India continues to progress towards urbanisation with almost 39 cities inhabiting more than a million people. The flagship programmes like Atal Mission for Rejuvenation and Urban Transformation (AMRUT) [4], Mission for development of 100 smart cities [5], Swachh Bharat Abhiyan [6] are continually working on making the Indian cities grow sustainably. To augment green innovations for resource conservation in India, a separate ministry named Ministry of New and Renewable Energy 
(MNRE) was formed which contribute to the objective of energy security of the government. The major strategy underlines subsidizing Research \& Development of the country to develop green and smart cities.

Hence, in this context, we emphasis to aggregate major innovative techniques fostered by both India and the Europe which led to significant preservation of the scarce natural resources. The mentioned techniques have somehow encapsulated the concept of 'circular economy' by maximally harnessing renewable resources, thus replacing conventional fossil fuels.

\section{BIOMASS GASIFICATION}

Growing concern for excessive utilization of the exhaustible natural resources has led to the emergence of various green technologies across the globe. Power generation from renewable sources has long been thought over as an alternative for such resources in order to develop greener and smarter cities. Biomass-to-energy conversion has well supported to the environment by substituting fossil fuels with carbon neutral energy emission, efficient waste management (due to utilization of waste), hydrogen production etc.

India has progressively been involved in harnessing the booming amount of biomass available in the country witnessing the rate of formation of 500 million metric tons per year [7]. Contribution of biomass energy in India is approximately one-third of the total energy consumed with biomass-based power generation being around 5941 MW till the year 2016 . Further, on-grid power generation has increased to $7907 \mathrm{MW}$ till the year 2017. For detailed report one can refer [8]. Fig. 1 gives year wise distribution of biomass based on-grid power production in India.

One of the inexorably rising technologies in biomass-based power production is biomass gasification. It includes conversion of biomass into a producer gas which is used in various heating and power generating systems. According to Faaij [10], gasification provides the possibility of zero or even negative carbon emissions. Under this process, high conversion efficiencies are attained in comparison to combustion. The producer gas formed can be economically transported to nearby locations. Moreover, cheap availability and cost-effective power generation from biomass makes this technology market driven. Hence, harnessing of energy from biomass via gasification route is not only economical, but also environmentally benign.

Notwithstanding the huge amount of biomass available, India faces challenges like: uneven distribution, inconsistent availability of biomass across the country and limited land area. Hence, India has largely gained expertise on state of the art of small scale gasifiers which are capable of being installed inside densely populated cities and overcome the above

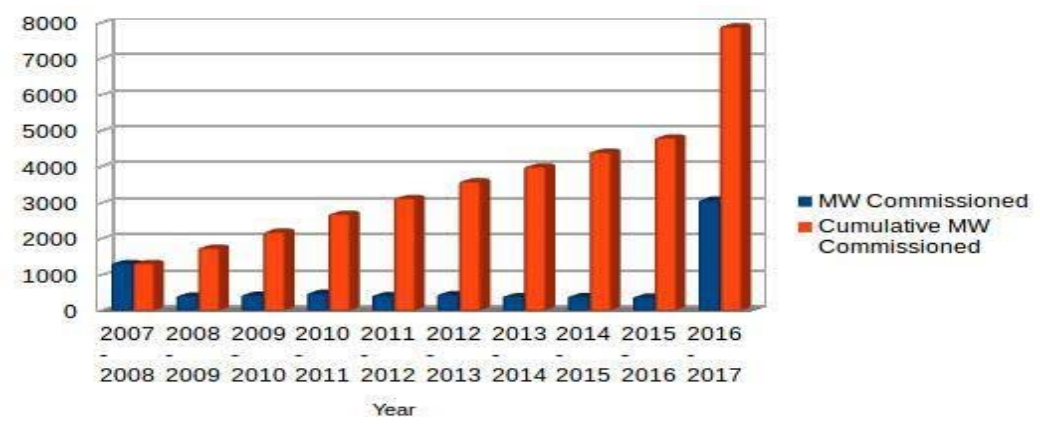

Figure 1: Biomass based on grid power production. (Source: [9].) 


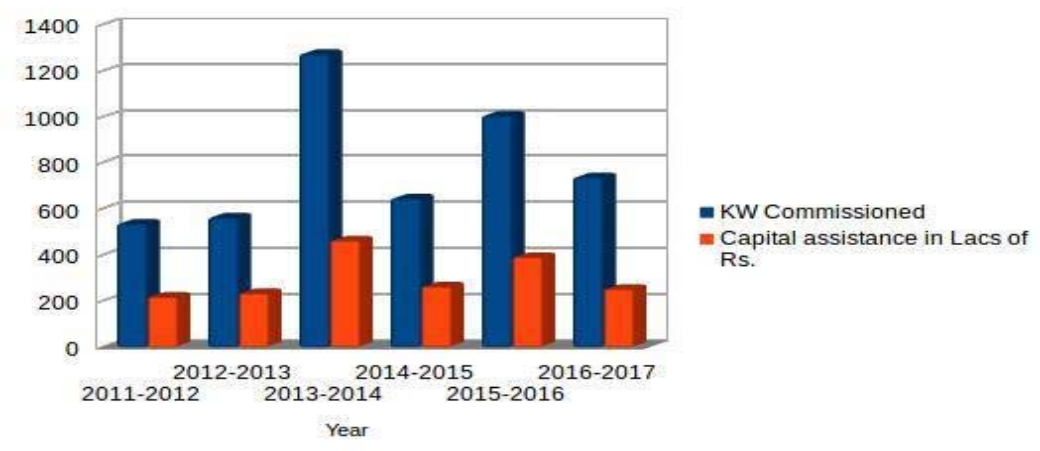

Figure 2: Capacity of off-grid projects commissioned, amount of capital assistance. (Source: [11].)

challenges as well. Government of India (GoI) proposed Biogas power (off grid) programme in the year 2013 for large scale circulation of the biogas plants (capacity range of $3 \mathrm{~kW}$ to $250 \mathrm{~kW}$ ) [12]. This will promote decentralized power generation in the country thereby reducing the cost of transportation of electricity and making remote areas self-sufficient.

Fig. 2 shows the year wise sanctioned biogas power projects under this programme from the period 2011-12 to 2016-17 showing power produced as well the funds sanctioned by the government.

\subsection{Research and development in India}

Tar formation during the process of gasification is one of the highly researched areas as it hinders the effortless functioning of the system by downstream blockage and low quality producer gas. According to European Union Biomass Industry Association (EUBIA), this acts as a major technical barrier for successful marketing of this technology [13]. Indian research institutes, in order to subjugate this problem have brought major changes in gasifier designs in addition to refinements in other features of systems.

Indian Institute of Science (IISc.) is one of the premier research institutes in India actively engaged in extraction of energy from biomass. This institute has also been actively involved in mapping its availability in the country since the 1980s [14]. Its continuous research in the area of biomass gasification has led to an improved, efficient and economically feasible open top re-burn downdraft gasifier [15]. Its distinct features have made it one of the best techniques for biomass gasification, outstanding some of the well-known gasifier designs. A total of more than 100 gasifiers based on this technology have been installed amounting to a total of more than $30 \mathrm{MW}_{\text {electric }}$ power generations in various countries of world. In Table 1, we compare some of the notable features of the technology with conventional downdraft gasifiers.

National Innovation Foundation (NIF), an autonomous body of government assisted by Department of Science and Technology (DST), Government of India has been actively engaged since year 2000 in supporting sustainability-driven innovations. NIF awarded one such innovation of Rai Singh Dahiya, a commoner who studied empirically the pre-installed gasifier systems in Hanumangarh district in the state of Rajasthan in India and developed a distinctive portable, compact and multiple-fuel two stage filters downdraft biomass gasifier [18]. The gasifier has an input capacity of $20 \mathrm{~kg}$ of bio-waste which after processing is 
Table 1: Notable features of the technology. (Source: [16], [17].)

\begin{tabular}{|l|l|l|}
\hline Parameters & $\begin{array}{l}\text { IISC DESIGNED } \\
\text { GASIFIER }\end{array}$ & $\begin{array}{l}\text { TYPICAL } \\
\text { DOWNDRAFT } \\
\text { GASIFIER }\end{array}$ \\
\hline $\begin{array}{l}\text { Calorific value of the producer } \\
\text { gas }\end{array}$ & $4.5-5 \mathrm{MJ} / \mathrm{kg}$ & $4.19-4.6 \mathrm{MJ} / \mathrm{kg}$ \\
\hline Cold gas efficiency & $78-82 \%$ & $67.65 \%-76.68 \%$ \\
\hline Tar level & $0.005 \mathrm{~g} / \mathrm{m}^{3}$ & $0.01-6 \mathrm{~g} / \mathrm{m}^{3}$ \\
\hline Specific consumption of wood & $1.2 \mathrm{~kg} / \mathrm{kWh}$ & $1.98 \mathrm{~kg} / \mathrm{kWh}$ \\
\hline Equivalence ratio & 0.25 & 0.27 \\
\hline
\end{tabular}

capable of running an engine of $30 \mathrm{HP}$. It has proved to be economically viable; with a cost less than half of other grid connected systems and requiring relatively less fuel consumption $(1 \mathrm{~kg} / \mathrm{k} \mathrm{VA})$. Its small size and portability makes it suitable for densely populated cities.

\section{FUEL FROM PLASTIC}

Solid waste management has been one of the primary concerns for developed as well as developing nations. Estimations by World Bank indicate a three-fold increase in the total waste generated by the year 2100 across the globe [19]. In response to such a menace, wastage of resources will have to be minimized by following the principle of 3R's (ReduceReuse-Recycle). Various conventional methods involving segregation, recycling, landfilling and incineration have proven to be inefficient for the sustainable management of more than a billion tonnes of waste generated annually in the cities. MNRE in its report of the year 2016 predicted, for 62 million tonnes of untreated waste, land required for landfill will be 340,000 cubic meters of space [20]. Therefore, one can infer shortage of land area for further disposal of tons of waste. On the other hand, treatment of waste by incineration is considered to be one of the primary reasons for air quality degradation.

Plastic is a commodious by-product of crude oil refineries. Major non-biodegradable constituent of total waste comprises of plastics which due to their flexibility, durability, and weightlessness have convoluted in our daily lives. It is non-biodegradable, chemically harmful for the ecosystem when burnt and lead to water, soil and air pollution. Hence, a technology which can mitigate such environmental threats will be well incorporated in the development of smart green cities. On the way of its maturity, there is one such green technology involving conversion of plastic-to-fuel (PTF) energy which has recently apprehended the attention from many governmental organizations and research institutes in countries like US, Germany, Japan and India. The processes are based on Pyrolysis (high temperature) and catalytic pyrolysis (relatively low temperatures). It converts low value plastics into value added fuel with extremely low harmful emissions and residual products.

\subsection{Fuel from plastic in India}

Central Pollution Control Board (CPCB) in its report, 2015 "Assessment \& Characterisation of Plastic Waste Generation in 60 Major Cities" mentions 3501 tonnes of plastic generated 
per day across 60 cities in India during the period from 2010 to 2012 [21]. The most common type of plastic generated in India is High Density Polyethylene (HDPE)/ Low Density Polyethylene (LDPE), sourcing mainly from households in cities of which 60 percent is collected and recycled whereas rest is dumped on-sites. To address this huge amount of waste, Government of India (GOI) under its flagship programme 'Swachh Bharat Abhiyan' plans to develop a modern and scientific system of solid waste management. The plastic waste management rules 2016 [22], published by Ministry of Environment Forest and Climate Change (MoEF) of GoI made provisions for recycling plastic waste with an effort to construct roads as per Indian Road Congress guidelines. Further, CPCB in its report "guidelines for co-processing of plastic waste in cement kilns" (2017) suggests the use of plastic waste as an alternative fuel for the cement industries hence conserving fossil fuels [21]. With extensive research in the area of PTF conversion, India has been successful in proffering solutions for efficient conversion techniques. A distinctive feature of such technologies is percentage conversion of plastic to usable substances which is more than $95 \%$ and can increase up to even $99 \%$.

\section{$3.2 \mathrm{R} \& \mathrm{D}$ in India}

Indian Institute of Petroleum (IIP), Council of Scientific and Industrial Research (CSIR) in collaboration with Gas Authority of India Limited (GAIL) have invented a breakthrough technology of converting plastic into petroleum products like diesel and gasoline, acting as a close substitute of conventional petroleum products. This innovation is distinctive in the sense that hardly any other process has been able to meet the standards for a transportation fuel which can be widely accepted in the market. The derived fuel has a better performance than traditional fuels in terms of distance/litre and emissions. Diesel and Gasoline obtained from this process gasoline from waste polyethylene meet the Euro-IV standards [23]. Fig. 3 shows the output product composition of this technology.

Awarded with India Innovation Initiative (I3), Ventana Ecogreen Inc. (R\&D centre in Haryana, India) has developed Plastic-To-Fuel technology following a series of patents by Amit Tandon, founder of this company. Their process turns plastic waste into industrial distillate fuel using continuous anaerobic thermal depolymerisation process. Continuity of the process is its distinctive feature as compared to previously practiced batch or semicontinuous processes. Production cost is as low as $\$ 10.9 /$ MMBTU which is better than cost of most of the fossil fuels. These features were presented by Ramakrishna Iyer (Head Engineering, Ventana Cleantech Inc.) at Wastech International Summit and Expo-2014 [24]. In Table 2, we mention relevant features of the above mentioned PTF technologies of India.

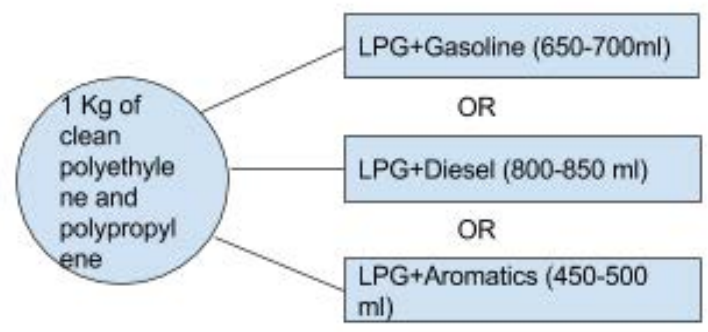

Figure 3: Output product composition of IIP technology. (Source: [23].) 
Table 2: Features of two PTF technologies of India. (Source: [23], [24].)

\begin{tabular}{|l|l|l|}
\hline $\begin{array}{l}\text { Qualities of Plastic to Fuel } \\
\text { designs }\end{array}$ & IIP design & Ventana Cleantech Inc. \\
\hline Use of liquid fuel & $\begin{array}{l}\text { Transportation/industrial } \\
\text { engines }\end{array}$ & Industrial engines \\
\hline Liquid fuel/Kg by weight & $\sim 70 \%$ & $\sim 74-82 \%$ \\
\hline Gaseous product generated & LPG $\sim 15-20 \%$ by wt. & LPG $\sim 12-20 \%$ by wt. \\
\hline Residue in \% of wt. & $0.1 \%$ (with clean plastic) & $4-8 \%$ \\
\hline Process type & Continuous (7-10) $\mathrm{kg} / \mathrm{hr}$. & Continuous $(50) \mathrm{kg} / \mathrm{hr}$. \\
\hline
\end{tabular}

\section{GREEN BUILDING}

The augmentation of urbanisation engenders construction of new buildings each year. Not only are they cause of deforestation, but also constitute the major sector of energy consumption and pollution. A summary report published by International Energy Agency on "Transition to sustainable Buildings" [25] mentions that buildings constitute one-third of the total energy consumption around the world in addition to large amount of $\mathrm{CO}_{2}$ emission. This brings an exigency for the cities to find solutions for mitigation of harm they cause to the environment.

A recent initiation towards sustainability has been taken in the form of green buildings which aims at zero carbon emissions as well as exploiting renewable sources like solar energy for electricity generation, hot water etc. together with healthy inner environment. Green buildings (as certified by Indian Green Building Council) can result into 40-50 percent energy saving and 20-30 percent water saving, in compared to other buildings [26]. With technological amelioration around the world, this green technology has proved to be an optimal solution for 'smart energy city' leading to efficient utilization of water, wind and other resources in addition to economic viability with low operation cost, reduced energy use, etc.

A worldwide network of Green Building Councils (GBC) [26] has been formed in order to strengthen smart and energy efficient mortgage plans with the goal of net zero carbon by the year 2030. It particularly focuses on economising, promoting awareness and technology related to the green buildings with the aim of adhering to the Sustainable Development Goals (SDG).

For the fulfilment of the year 2030 targets of reducing emissions of greenhouse gases by 40 percent, EU has inaugurated Energy efficient Mortgages Action Plan (EeMAP) to bridge the gap between the financial hindrance and construction of green buildings encompassing the largest number of net zero carbon buildings in the world. The details of the plan can be found at [27].

\subsection{Green lighthouse}

University of Copenhagen, Denmark has remarkably contributed to becoming a 'green campus' while building Denmark's first public sustainable building. The two-storey building 
inaugurated in the year 2009 has been well designed for maximizing solar and geothermal energy use, salubrious indoor ventilation, limited use of water resource and district heating etc. making it an exemplary example of technology integrated with sustainability. The building is built so as to reduce energy consumption up to 70 percent using sun as the main source of energy through solar panels. Renewable energy production is as high as $20 \mathrm{kWh}$ $\mathrm{PE} / \mathrm{m}^{2}$ making it highly energy efficient. Taking inspiration from its infrastructure, many countries have initiated the green building projects in their respective universities or colleges making efforts to reduce the $\mathrm{CO}_{2}$ emissions in addition to the cost involved with it. Other specifications can be obtained from [28].

\subsection{The edge}

In a recent study [29], enhanced ventilation systems have been regarded as one of the factors influencing the productivity of office workers. Cost involved in improving the ventilation systems per occupant were quite low, but the productivity increased by 150 times. Therefore, it can be believed that green offices may have a positive environmental as well as economic impact. Smart city of Amsterdam possesses one such model of green office, The Edge [30], thus being an example to the above claims. The 15-storey green office located in The Zuidas, Netherlands has been a contemporary innovation which directly affects health of the office workers and thereby their work efficiency. The building incorporates many renewable resource-oriented technologies and is one of the most sustainable buildings in the world. It has also been awarded as the best sustainable office by Building Research Establishment (BRE). The key feature of this office being instalments of Philips' Ethernet-powered LED connected lightings in each storey allowing workers to personalize their lighting and temperature via a mobile app thus enhancing the quality of work environment with energy management. For other specifications of the building, one can refer [30].

\section{GREEN PUBLIC TRANSPORTATION}

Black Carbon emissions are next to $\mathrm{CO}_{2}$ emissions for imposing a serious threat to environment and hence result into climate change. It mainly originates from the transportation sector due to the usage of diesel as transportation fuel. Not only are they cause of urban air pollution but are also responsible for noise pollution thereby degrading the productivity of population. In order to mitigate the adverse environmental impact and reduce congestion in the cities, green public transportation seems a well-suited alternative.

Cars in EU account to $12 \%$ of $\mathrm{CO}_{2}$ emission [31]. With a constant rise in diesel consumption for transport amounting to 73 percent of the total fuel sales in the year 2015, a need has arisen to build an efficient transportation system so as to reduce diesel consumption. The "Horizon 2020" program, which aims at better mobility, has well supported green innovations by providing proper funding. Smart mobility such as electric buses and trams has resulted in significant reduction of private car use by giving comfort and healthy indoor environment to the passengers. Europe has made extensive progress in building a network of tramways and electric buses which consume less energy with less than zero emissions.

\subsection{Electric buses}

Smart city of Vienna, Austria has progressed to a great extent in ensuring a transportation system which is reliable, economical and eco-friendly. The Urban Mobility Plan (UMP) initiated in the city aims for viable mobility for population of 3 million reducing personal motorised transport to less than 20 percent by the year 2025 [32]. For its attainment, Viennese 
have adopted the innovative technology of electric buses which tends to reduce emissions, thus a viable alternative for the diesel and LPG buses. Such initiatives have also been planned out in other cities of EU like Amsterdam. The buses run on batteries which are recharged at the end stations through trams overhead power lines where battery as well the inverter is fixed inside the bus. Due to a large tram network built in the city, charging process is smoothly carried out. A notable feature is the recharging time taken by the bus to fully charge which ranges from 5 to 8 minutes. Between the two recharging time period, bus can cover a total distance of 150 kilometres. Due to production of only a few, costs of the bus purchase remains quite high, although with the increment in the production, low purchase costs are expected. Besides high purchasing cost, maintenance cost is as low as $€ 8$ per year. Moreover, on the environmental side, these buses have lower emissions of $\mathrm{CO}_{2}(5.3 \mathrm{t}), \mathrm{NO}(1.7 \mathrm{t})$, and $\mathrm{NO}_{2}(0.06 \mathrm{t})$ in comparison to LPG buses [33].

\section{SCHEMES AND NATIONAL PROGRAMMES FOR SUSTAINABLE ENERGIES}

\subsection{Swachh Bharat urban mission}

Launched in the year 2014 by Ministry of Urban Development, Swachh Bharat Mission (Urban) [4] had the vision of 'clean India' with objectives of attaining efficient solid waste management, eradication of open defecation, managed sanitation systems etc. The issue of open defecation is prominent in developing countries where one finds lack of sanitation systems, technologies for managing the tonnes of waste produced and awareness of the impacts of it on the environment. This mission, therefore, aims at improving the sanitation status of the country.

Swachh Survekshans [4] conducted by GoI in few major cities of India in order to assess the progress towards achieving above mentioned goals show a constant amelioration in the environment of the targeted cities. To mention, cities like Indore, Bhopal, Surat have well managed waste collection techniques making a segregation of the dry and the wet waste where plastics collected from the households are utilized for the construction of roads, thus minimizing the resource utilization and wastage. All the clean and smart cities have system of tracking garbage trucks and auto trippers using GPS/RFID. Hence, Swachh Bharat

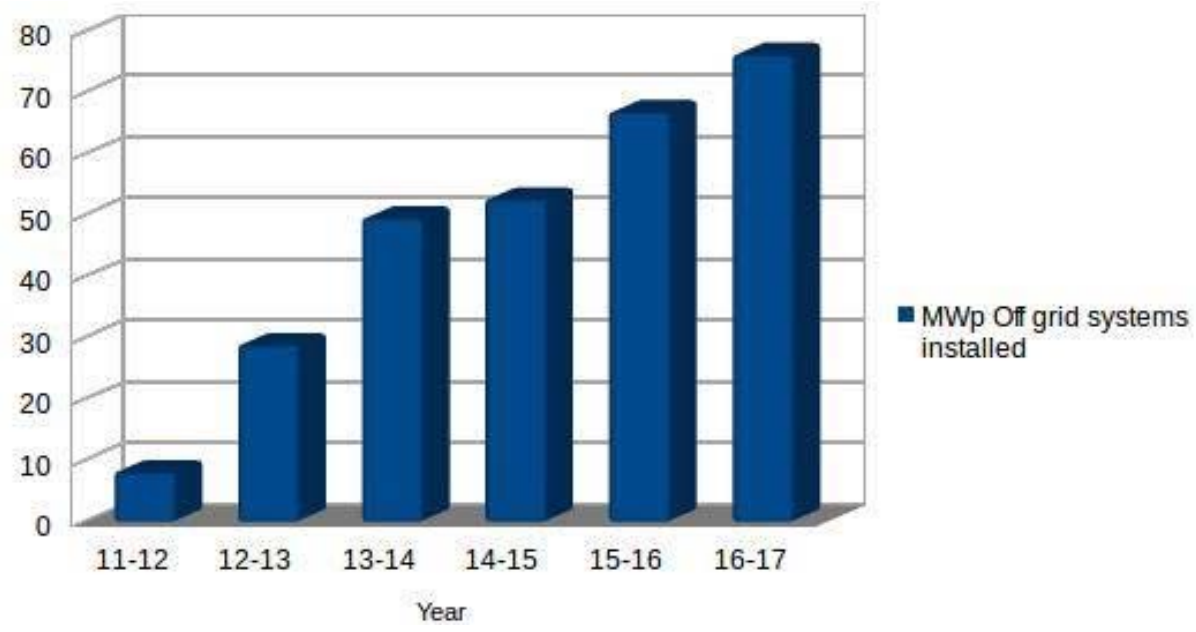

Figure 4: Year-wise installed capacity of off-grid solar power. (Source: [9].) 
Mission (SBM) seems to have a notable positive impact on the sustainably growing smart cities.

\subsection{National solar mission}

One of the major initiatives made in India in terms of sustainable economic growth was the Jawaharlal Nehru National Solar Mission (now called National Solar Mission) launched on 11th January 2010 [9]. The prime emphasis of the following mission was to promote solar energy exploitation reducing its cost for energy production. The programme targets are:

- Deployment of 20,000 MW of grid connected solar power by the year 2022

- 2,000 MW of off-grid solar power by the year 2022

- 20 million sq. m. solar thermal collector area

Analysing potential of India in harnessing solar power (approximately 300 sunny days), the target of establishing 20,000 MW of grid connected solar power was revised to 100,000 MW in the scheme. The scheme identifies the importance of large scale solar plants in reducing the cost for power generation, hence incorporates the establishment of 25 solar parks, each with a capacity of $500 \mathrm{MW}$ and above [34]. Phase 1 of the programme witnessed more power generated from the solar projects (1,938.94 MW) than was targeted (1300 MW). Year-wise progress of the programme is shown in Fig. 4 from the period from 2011-12 to 2016-17 of the off-grid solar installations in India.

\subsection{City vitality and sustainability (CIVITAS)}

CIVITAS [35] is a European initiative launched in the year 2002 for supporting smart, innovative and sustainable solutions for mobility. Being well aware of the significance of research and development in achieving the target, this program provides all kinds of support to the projects which can alter conventional technologies being followed. Since its launch, there have been number of successful tests and inventions improving the transport structure of European cities. It promotes integration of clean fuel, well-managed and safe motor drive in order to attain a smooth transportation system in EU. Few of the projects undertaken in this programme are related to traffic management, parking infrastructure for the vehicles, eco-friendly bikes and promotion of non-motorized vehicles. CIVITAS promotes the use of electric vehicles in the place of conventional public transport buses and cars. There have been about 10 successful innovative measures in this concern few of which are mentioned as under:

- Hybrid buses - energy saving amounting to 20 percent than usual

- Green tariff - an incentive in the form of reduced taxes in parking area for the drivers of green vehicles

- Charging points for electric vehicles established at charging centres

- Electric municipal car sharing scheme

- For other mobility initiatives undertaken in this programme, one can be referred [36]

\section{LESSONS FOR THE WORLD}

1. For countries facing challenges like: uneven distribution of biomass, limited land area and high density of population, small scale gasification plants should be preferred technological options. These gasifiers can be easily installed inside the cities nearer to households or small-scale industries for effective power generation. 
2. Technological upgradations made by the premier institutes of India in the context of gasifier designs can be well incorporated by other gasifier systems around the world.

3. Conventional methods for disposing off the plastic waste should be scaled down due to their negative impact on the environment. It can be replaced by upcoming green technologies of extracting fuel from plastics.

4. For economic benefits such as low transportation cost, Plastic to Fuel plants should be set up nearby the landfill sites of the dumped waste which are mostly in the outskirts of the cities.

5. Newly constructed buildings in the cities such as offices, universities or colleges should adopt the essential features of norms of green buildings. For its promotion, government should provide incentives like reduction in the existing taxes (Ex. property tax) on the green buildings.

6. For countries with a system of tram network, electric buses are a viable option instead of diesel and LPG buses. These buses are having low maintenance cost and fast recharging features which will prove to be beneficial in the long run.

7. Waste plastics can be used for the construction of roads, as it is done in few of the cleanest cities in India.

8. Tropical countries with high intensity of sunlight should promote off-grid solar plants which includes solar lamps, solar street lights etc. for reducing a great extent the complexity of lightning system in cities and making itself sustainable.

9. Smart cities heavily depend on innovations; thus policies should be implemented by supporting research and development on green technologies continuously. Moreover, supporting agencies should be setup which evaluates the feasibility and applicability of such innovations for sustainable smart cities.

\section{CONCLUSION}

For a growth of green and smart cities, India has grown its potential in recent years to mitigate the environmental pressure caused by its rapidly increasing urban population. In order to combat its resource deficiency problem, India has come up with innovative and novel techniques to substitute the conventional fossil fuels. Government of India is having projects to fund, support and strengthen any type of plan that formulates and measure to secure environmental security and sanctity.

Further, recently deployed green technologies in smart cities of EU inspire other countries to incorporate them in their smart city growth. Present work informs about some of the breakthrough technologies made by both India and Europe for their green and sustainable growth. Lessons learned from India and European experiences on the green technologies can be well-incorporated in the policies of other countries for green technological growth to achieve the goal of sustainable smart cities.

\section{ACKNOWLEDGEMENTS}

The authors would like to thank Ayushi Dube (First author's sister), Rishabh Jha (Gaya University), Himanshu Shukla (IIT Kanpur) for their valuable suggestions and Dr. Sanat Kumar (IIP, Dehradun) for helping with the valuable information on their technology.

\section{REFERENCES}

[1] The World's Cities in 2016: Data Booklet, Online. http://www.un.org/en/ development/desa/population/publications/pdf/urbanization/the_worlds_cities_in_20 16_data_booklet.pdf. Accessed on: 7 Oct. 2017. 
[2] European Commission - European Commission. Europe 2020 strategy, Online. https://ec.europa.eu/info/business-economy-euro/economic-and-fiscal-policycoordination/eu-economic-governance-monitoring-prevention-correction/europeansemester/framework/europe-2020-strategy_en. Accessed on: 8 Jan. 2018.

[3] GDP Ranking Data, Online. http://data.worldbank.org/data-catalog/GDP-rankingtable. Accessed on: 8 Jan. 2018.

[4] Amrut.gov.in, Online. http://amrut.gov.in/. Accessed on: 7 Jan. 2018.

[5] Smart Cities Mission, Online. http://smartcities.gov.in/content/. Accessed on: 7 Jan. 2018.

[6] Swachh Bharat, Online. http://www.swachhbharaturban.in/sbm/home/\#/SBM. Accessed on: 7 Jan. 2018.

[7] Mnre.gov.in, Ministry of New and Renewable Energy - Biomass Power/Cogen, Online. http://mnre.gov.in/schemes/grid-connected/biomass-powercogen/. Accessed on: 7 Jan. 2018.

[8] Biomasspower.gov.in, Biomass website, Online. http://biomasspower.gov.in /About-us-3-Biomass\%20Energy\%20scenario-4.php. Accessed on: 7 Jan. 2018.

[9] Mnre.gov.in, Ministry of New and Renewable Energy - Annual Reports, Online. http://mnre.gov.in/mission-and-vision-2/publications/annual-report-2/. Accessed on: 7 Jan. 2018.

[10] Faaij, A., Modern biomass conversion technologies. Mitigation and Adaptation Strategies for Global Change, 11, pp. 343-375, 2006.

[11] Mnre.gov.in, Online. http://mnre.gov.in/file-manager/offgrid-biomass-gas-schemes /biomassgasifier-prohramme-for-12th-five-year-plan.pdf. Accessed on: 7 Jan. 2018.

[12] Statewise_commissioned-installed_Biogas_offgrid_Power_Projects.pdf, Online. http://mnre.gov.in/file-manager/UserFiles/Statewise $\% 20$ commissionedinstalled_Biogas_offgrid_Power_Projects.pdf. Accessed on: 8 Jan. 2018.

[13] Eubia.org, Gasification - European Biomass Industry Association, Online. http:// www.eubia.org/cms/wiki-biomass/pyrolysis-and-gasification/gasification/. Accessed on: 7 Jan. 2018.

[14] Cgpl.iisc.ernet.in, CGPL Biomass Atlas, Online. http://cgpl.iisc.ernet.in/site /Biomass-Atlas. Accessed on: 7 Jan. 2018.

[15] Cgpl.iisc.ernet.in, CGPL > Technologies > Biomass-Gasification, Online. http://cgpl.iisc.ernet.in/site/Technologies/Biomass-Gasification. Accessed on: 7 Jan. 2018.

[16] Cgpl.iisc.ernet.in, Online. http://cgpl.iisc.ernet.in/dasappa/img/pdf/thesis/Sadhan Thesis_July16.pdf. Accessed on: 7 Jan. 2018.

[17] Zainal, Z.A., Rifau, A., Quadir, G.A. \& Seetharamu, K.N., Experimental investigation of a downdraft biomass gasifier. Biomass and Bioenergy, 23, pp. 283-289, 2002.

[18] Nif.org.in, Bio-Mass Gasifier System | National Innovation Foundation - India, Online. http://nif.org.in/innovation/Biomass_based_gasifier/6. Accessed on: 7 Jan. 2018.

[19] World Bank, Global Waste on Pace to Triple by 2100, Online. http://www.worldbank. org/en/news/feature/2013/10/30/global-waste-on-pace-to-triple. Accessed on: 7 Jan. 2018.

[20] 164.100.47.193, Online. http://164.100.47.193/lsscommittee/Energy/16_Energy_20. pdf. Accessed on: 7 Jan. 2018.

[21] Central Pollution Control Board $>>$ Programme/projects $>$ Waste $>$ Bio-Medical Waste, Online. http://164.100.107.13/Plastic_waste.php. Accessed on: 8 Jan. 2018. 
[22] Moef.gov.in, Online. http://www.moef.gov.in/sites/default/files/PWM\%20Rules\%2C \%202016.pdf. Accessed on: 7 Jan. 2018.

[23] Iip.res.in, Welcome to CSIR-Indian Institute of Petroleum, Online. http://www. iip.res.in/. Accessed on: 9 Jan. 2018.

[24] Gpcb.gov.in, Session 2A, Online. http://gpcb.gov.in/session-2a2.htm. Accessed on: 7 Jan. 2018.

[25] iea.org, Online. http://www.iea.org/Textbase/npsum/building2013SUM.pdf. Accessed on: 7 Jan. 2018.

[26] Worldgbc.org, The benefits of green buildings/World Green Building Council, Online. http://www.worldgbc.org/benefits-green-buildings. Accessed on: 7 Jan. 2018.

[27] Energyefficientmortgages.eu, Online. http://energyefficientmortgages.eu/wp-content /uploads/2017/06/EeMAP-Two-page-introduction.pdf. Accessed on: 7 Jan. 2018.

[28] Build Up. Green Lighthouse: Denmark's first public carbon-neutral building, Online. http://www.buildup.eu/en/practices/cases/green-lighthouse-denmarks-first -public-carbon-neutral-building. Accessed on: 7 Jan. 2018.

[29] MacNaughton, P., Pegues, J., Satish, U., Santhanam, S., Spengler, J. \& Allen, J., Economic, environment and health implication of enhanced ventilation in office buildings. International Journal of Environmental Research and Public Health, 2015.

[30] BREEAM, The Edge, Amsterdam, Online. http://www.breeam.com/offices /the-edge-amsterdam/. Accessed on: 7 Jan. 2018.

[31] Climate Action - European Commission. Reducing CO2 emissions from passenger cars - Climate Action - European Commission, Online. https:/ec.europa.eu/clima/ policies/transport/vehicles/cars_en. Accessed on: 8 Jan. 2018.

[32] STEP 2025 - Urban Mobility Plan Vienna - Werkstattbericht 155, Online. www.wien. gv.at/stadtentwicklung/studien/pdf/b008443.pdf. Accessed on: 7 Jan. 2018.

[33] Clean-fleets.eu, Online. http://www.clean-fleets.eu/fileadmin/files/Clean_Fleets_case study Vienna - Final.pdf. Accessed on: 7 Jan. 2018.

[34] Mnre.gov.in, Ministry of New and Renewable Energy - Scheme/Documents, Online. http://www.mnre.gov.in/solar-mission/jnnsm/introduction-2/. Accessed on: 7 Jan. 2018.

[35] Civitas.eu, Civitas Initiative | Clean and Better Transport in Cities, Online. http://civitas.eu/. Accessed on: 7 Jan. 2018.

[36] Civitas.eu, Exploring Mobility Solutions Civitas Initiative, Online. http://civitas.eu/ mobility-measures. Accessed on: 9 Jan. 2018. 